\title{
ABO A1 Subtype Determination
}

National Cancer Institute

\section{Source}

National Cancer Institute. ABO A1 Subtype Determination. NCI Thesaurus. Code C135397.

The characterization of the $\mathrm{ABO}$ blood group $\mathrm{A} 1$ subtype in an individual. 